\title{
Does social couponing stimulate positive eWOM and online referrals? ${ }^{1}$
}

\author{
Fabio Cassia - Francesca Magno - Marta Ugolini
}

\begin{abstract}
Purpose of the paper: Social couponing campaigns are becoming increasingly popular among hotels. However, while their short-term impacts have been assessed, their medium and long-term benefits for the hotels' reputation have not been measured yet. The purpose of this study is to provide evidence of the potential of social couponing to stimulate positive electronic word-of-mouth (eWOM) and online referrals to hotels. In addition, this research intends to identify the factors related to the design and management of the couponing campaign, which influence the couponers' willingness to engage in positive eWOM and referrals.

Methodology: The study is based on the content analysis of 564 TripAdvisor reviews posted by guests that have stayed at 76 Italian hotels using a Groupon's coupon. Both frequency and co-occurrence analysis are performed.

Findings: The results show that social couponing stimulates intense positive eWOM and referrals. The analysis also highlights the most important coupon-related factors, which are able to influence the valence (positive vs. negative) of the eWOM.

Research limits: The small sample of hotels, considered in this research and the specific features of the Italian hotel industry suggest caution in generalizing the results to other settings.

Practical Implications: Hotel managers should design and manage their couponing campaigns carefully considering several factors, identified by this study, which directly stimulate positive eWOM. The findings of this research also suggest that hotel managers could use couponing campaigns as effective tools for their online reputation management strategies.

Originality of the paper: This paper provides empirical evidence of the eWOM and referral effects of social couponing. Hence, it complements previous studies, which have mostly considered the short-term effects of social couponing related to sales increase.
\end{abstract}

Key words: social coupons; daily deals; flash sales; hotels; electronic word-of-mouth; eWOM

\section{Introduction}

Social couponing (labeled also as flash sales or daily deals) is a form of sales promotion that has enjoyed widespread popularity among hotels in the last few years (Berezina et al., 2016; Cassia et al., 2015; Minazzi, 2015; Piccoli and Dev, 2012). It consists of "an intermediary that manages a list of

1 Best paper for the $18^{\text {th }}$ Toulon-Verona Conference "Excellence in Services",

Palermo (Italy), 31 August - 1 September 2015. 
sinergie Vol. 34, N. 100, 2016

subscribers through e-mail and social media, and offers merchants access in exchange for a commission, allowing them to promote their offerings at a steep discount" (Boon et al., 2015, p. 3). Up to now, social couponing campaigns have been used by hotels with the primary aim of selling their unsold room inventory (Yang et al., 2015). Hence, hotel managers have mostly considered this tool for its potential to provide short-term incentives to stimulate purchases (Yang et al., 2015).

However, different from traditional coupons, social coupons not only have the potential to promote short-term sales, but may be also used by hotels to increase their brand awareness (Berezina et al., 2016). In fact, daily deal reach a number of subscribers which is much higher than the number of deal purchasers. In addition, these deals are designed to stimulate viral effects and online conversations (Boon, 2013; Boon et al., 2012). For example, daily deal sites include features that allow consumers to share deals via social networks (Nakhata and Kuo, 2014). In addition, deal campaigns' limited duration is used to stimulate intense and quick referrals (Drossos et al., 2015; Lo et al., 2014). Hence, the e-word-ofmouth (eWOM) and the referral value should be carefully considered to appreciate the overall effectiveness of a social couponing campaign (Kumar and Rajan, 2012). Nonetheless, when evaluating the effectiveness of social couponing, hoteliers seem to overlook the social aspects of social couponing (Cassia et al., 2015). This is not surprising as operators are still learning how best to use daily deals (Piccoli and Dev, 2012). Until recently, academic research has also largely overlooked the social effects of this marketing tool.

In the last few years (and particularly in 2014 and 2015), several studies have started to examine deal subscribers' purchase, redemption and after-consumption behaviors, highlighting the social aspects of social couponing in general, and in the hotel industry in particular (Cox, 2015). Nonetheless, this stream of studies still presents two main limitations.

First, these contributions focus only on the effects of eWOM among daily deal users and they do not consider the impact on regular customers, i.e. customers staying at the hotel without a coupon. In sum, these studies conclude that the decision to purchase deals is influenced by the recommendation made by other coupon users. However, if coupon users have a satisfying (vs. unsatisfying) experience at the hotel, they may engage in positive (vs. negative) eWOM, thus acting as brand ambassadors (vs. detractors) and improving (vs. damaging) the overall hotel reputation, with effects on both coupon users and regular customers. Second, available studies do not quantify the amount of this positive vs. negative eWOM stimulated by social couponing.

The purpose of this study is to contribute to fill these gaps, by establishing whether, in the hotel industry, social couponing is able to stimulate positive eWOM and referrals on the most prominent travel review site, TripAdvisor. In detail, this study intends to reach two aims:

- assessing the amount of positive vs. negative eWOM and referral generated on TripAdvisor by coupon users that stayed at a hotel;

- identifying the coupon-related factors that are able to explain the valence (positive vs. negative) of the eWOM. 
For this purpose, this study presents the results of the analysis of the customer reviews on TripAdvisor posted by guests that stayed at 76 Italian hotels using daily deals.

From a theoretical perspective, the findings of this study will provide empirical evidence of the social effects of the daily deals, thus advancing available knowledge about social couponing in the hotel industry (Berezina et al., 2016; Cassia et al., 2015) and social commerce (Yadav et al., 2013). The results will also enrich available knowledge about eWOM management in the hospitality sector (Baka, 2016; Schuckert et al., 2015).

From a managerial perspective, this study provides hotel managers with new evidences to perform a comprehensive evaluation of social couponing effectiveness. Several hotel managers show a medium-to-low level of satisfaction with this marketing tool, mainly due to its ineffectiveness to attract loyal customers (Piccoli and Dev, 2012). Our findings make managers appreciate the additional social effects of social couponing which may compensate for the low number of returning customers. The results may also assist managers in designing their strategy when managing eWOM.

The remainder of the paper is articulated as follows. The next section presents a review of the literature on social couponing, with the purpose of highlighting the relationship between social couponing and eWOM. After that, the methods and the results are presented. Discussion and conclusions complete the paper.

\section{Social couponing and eWOM}

\subsection{Overview of the social couponing literature}

Social coupons are prepaid online discount vouchers offered by merchants (e.g. hotels, spas, and restaurants) through daily deal websites, such as Groupon, LivingSocial and others (Kumar and Rajan, 2012; Ong, 2015). Social couponing started to take off in 2008, when the current market leader - Groupon - was founded. Consequently, the popularity of this phenomenon has attracted the interest of academic researchers in the last few years. In particular, the work by Kumar and Rajan (2012) may be considered the first comprehensive scientific conceptualization about social couponing. Recently scholars from several disciplines (marketing, hospitality and information technology) have addressed this phenomenon from the perspectives of its different participants: coupon users, daily deal websites and aggregators, merchants. In sum, the social couponing literature has covered the following issues:

- the general functioning of social couponing (Kumar and Rajan, 2012; Sigala, 2013);

- factors explaining the performance of daily deal campaigns (Eisenbeiss et al., 2015; Song et al., 2016; Subramanian and Rao, 2016);

- popularity, benefits, drawback and management of social couponing for merchants in general (Aday and Phelan, 2015; Lee and Lee, 2012) or with a specific focus on restaurants (Heo, 2016; Kimes and Dholakia, 2011; Wu et al., 2012), hotels (Berezina et al., 2016; Cassia et al., 2015), health and wellness businesses (Lee, 2016);
Fabio Cassia

Francesca Magno

Marta Ugolini

Does social couponing stimulate positive eWOM and online referrals 
- role, strategies and operations of daily deal websites (Krasnova et al., 2013) and daily deal aggregators (Blanco et al., 2015);

coupon users' attitudes and behaviors focusing on the purchase phase (Cheah et al., 2015; Coulter and Roggeveen, 2012; Luo et al., 2014; Nakhata and Kuo, 2014; Parsons et al., 2014), the redemption phase (Nakhata and Kuo, 2016) and the after-consumption phase (Cox, 2015).

A few studies have specifically examined the relationship between social couponing and eWOM, which represents the focus of this study. This stream of literature is reviewed in the next section.

\subsection{The relationship between social couponing and eWOM}

Deals users' engagement in rich eWOM is often reported as a distinctive feature of social couponing compared to traditional couponing (Lee et al., 2015). However, empirical knowledge on this issue is scarce (Boon et al., 2015). Only recently, contributions have started to investigate daily deal subscribers' purchase, redemption and after-consumption behaviors, including eWOM.

This new stream of research has highlighted that eWOM, generated by deal purchasers, may drive other people to buy the deals. When daily deal subscribers receive deal newsletters, most of them decide to buy only one deal or none at all (Boon et al., 2015).

This often happens because deals are mainly offered by local merchants and consumers are often unfamiliar with their brands (Luo et al., 2014; Nakhata and Kuo, 2014). In addition, several consumers resist because they think that using deals would make them look cheap (Boon, 2013). Hence, subscribers look for suggestions and reviews of purchasers that have already bought and redeemed the coupon. Therefore, eWOM generated by deal purchasers is highly influential.

Based on these premises, Luo et al. (2014) reported that a deal popularity (expressed by the cumulative amount of deals purchased by other people) increases a consumer's purchase likelihood and reduces the time the consumer will take to redeem the deal. In addition, this effect is amplified by customer referral intensity.

Similarly, Nakhata and Kuo (2014) found that consumer rating (consumer evaluation after consumption) and the number of purchased social coupons have a substantial impact on purchase likelihood of social coupons, especially for low variety seekers consumers, i.e. for consumers perceiving greater risk. Finally, Ong (2015) demonstrated that daily deal purchasers (in particular those that are highly satisfied with the redemption of the deal) show better attitudes toward daily deals and are particularly active in referring them to their friends. Moreover, their reviews of deals are fundamental to enhance the credibility of daily deals in general.

Therefore, recent studies have found that the eWOM activated by coupon users is able to persuade other people interested to buy the deal. However, these studies have not considered that the mentioned eWOM may have a persuasive effect on regular customers (i.e., customers staying at a hotel without a coupon). 
A significant exception is the work by Cox (2015), who analyzed online travel reviews posted on a prominent website (that is a recognized leader in online reviews for the tourism industry) by guests who stayed at some Australian hotels using a coupon. This website is visited not only by people evaluating whether to buy a deal for a specific hotel, but also by potential "regular customers". Therefore, the eWOM generated by couponers on this website may influence both other couponers and regular customers. Cox (2015) found that about 55\% of the guests recommended the hotel favorably. Nonetheless, her study did not present an in-depth analysis of eWOM valence and of the factors that are statistically correlated with positive vs. negative eWOM. This paper aims to contribute to fill these gaps.

\section{Methods}

A qualitative approach similar to the one adopted by Cox (2015) was applied. In detail, we analyzed 564 reviews posted on TripAdvisor by guests that stayed at 76 Italian hotels using Groupon's coupons. Groupon is the leader in the Italian daily deals market with about $50 \%$ of the market share (Magno et al., 2014a; Magno et al., 2014b). To identify the 564 reviews, we followed this procedure. First, we selected 76 hotels which, based on our previous studies (Magno et al., 2014a), had run at least one coupon campaign through Groupon before October 2012.

Then, we collected all customer reviews published up to the end of June 2015 on TripAdvisor for the 76 hotels, obtaining 14,416 reviews. These reviews were carefully analyzed to select those making explicit reference to Groupon. Through this analysis, we found 564 reviews of guests that explicitly stated that they stayed at one of the 76 hotels using a Groupon's coupon.

We then coded each of the 564 reviews (Capriello et al., 2013) with the support of the software Dedoose. Comments were coded independently by the authors of this paper. In defining the codes, we followed the process suggested by Saldaña (2009).

Initially we used codes (for eWOM valence, intention to recommend and coupon-related factors explaining the performance of the couponing campaign) based on the findings of previous literature about eWOM and social couponing. After this initial step, codes were refined and new codes were added to reflect new concepts, which emerged during the first part of the analysis. In case of disagreement, discussion took place among the authors to end up with an agreed-upon codification.

Through this process, each comment was classified as a source of positive, neutral or negative eWOM. Several magnitudes of referrals were identified, as well, including: unconditional recommendation to stay at the reviewed hotel; recommendation to stay at the reviewed hotels only with a coupon; recommendation not to stay at the reviewed hotel.

As regards the factors that explain the positive / negative valence of the eWOM, we did not search for general antecedents of satisfaction, such as hotel facilities or cleanliness. 
sinergie Vol. 34, N. 100, 2016

Only factors related to the daily deal were of interest for this study and therefore only these aspects were coded and analyzed. For example, we did not consider price per se, but we included the impact of price on couponers' expectations: because of the low price paid for staying at the hotel, some couponers reported they had lower pre-stay expectations (the code "Expectations: Lower for couponers (value for money)" was used for this concept).

In detail, the following codes were used:

- eWOM: Negative;

- eWOM: Neutral;

- eWOM: Positive;

- Recommend: No;

- Recommend: Yes;

- Recommend: Only with coupon;

- Expectations: Lower for couponers (value for money);

- Expectations: Unmet expectations;

- Expectations: Met expectations;

- Expectations: Beyond expectations;

- Expectations: Worried (negative reviews);

- Booking-related problems;

- Differences between advertised and real conditions;

- Lack of transparency;

- Push to purchase additional services;

- Treatment: B-level treatment;

- Treatment: Treated as regular customers;

- Attempts to "cheat" the couponers.

We then analyzed the frequency of each code and we estimated the co-occurrence of positive/negative eWOM and of the identified factors through a correlation analysis.

To offer further evidences, each of the hotel ratings (from 1 to 5) provided on TripAdvisor by the authors of the 564 reviews was compared with the average rating of the hotel being evaluated to ascertain whether coupon users' evaluations were similar to the average evaluations.

\section{Results}

Table 1 provides the frequencies with which each code came up in the reviews. The results show that the positive eWOM $(n=380)$ largely prevails over negative eWOM $(n=94)$ and neutral eWOM $(n=90) .112$ explicit positive recommendations were also registered, compared with only 18 reviews which advised readers not to stay at the hotel. 
Tab. 1: Frequencies of codes

\begin{tabular}{|l|l|c|}
\hline \multicolumn{2}{|c|}{ Codes } & Frequency \\
\hline \multirow{3}{*}{ eWOM } & Negative & 94 \\
\cline { 2 - 3 } & Neutral & 90 \\
\cline { 2 - 3 } & Positive & 380 \\
\hline \multirow{3}{*}{ Recommend } & Yes & 112 \\
\cline { 2 - 3 } & No & 18 \\
\cline { 2 - 3 } & Only with coupons & 8 \\
\hline & Lower for couponers (value for money) & 81 \\
\cline { 2 - 3 } & Unmet expectations & 8 \\
\cline { 2 - 3 } & Met expectations & 17 \\
\cline { 2 - 3 } & Beyond expectations & 58 \\
\cline { 2 - 3 } & Worried (negative reviews) & 24 \\
\hline \multirow{3}{*}{ Treatment } & B-level treatment & 30 \\
\cline { 2 - 3 } & Treated as regular customers & 21 \\
\hline Booking-related problems & 26 \\
\hline Differences between advertised and real conditions & 26 \\
\hline Lack of transparency & 37 \\
\hline Push to purchase additional services & 23 \\
\hline Attempts to "cheat" the couponers & \\
\hline
\end{tabular}

Source: our analysis

In addition, we calculated the average rating provided by the 564 guests that stayed at the 76 hotels with a coupon, obtaining a value of 3.66 (on a 5 -point scale). This value was slightly, but significantly lower $((t) 563)=4.68$; $\mathrm{p}<0.01)$ than the average value provided by the average customers for the same hotels, which was equal to 3.88. Table 2 shows the detailed frequencies of the 564 evaluations.

Tab. 2: Frequencies of the ratings provided by the 564 guests that used a coupon

\begin{tabular}{|c|c|}
\hline Rating & Frequencies $(\mathrm{n}=564)$ \\
\hline 1 & $42(7.4 \%)$ \\
\hline 2 & $45(8.0 \%)$ \\
\hline 3 & $117(20.7 \%)$ \\
\hline 4 & $217(38.5 \%)$ \\
\hline 5 & $143(25.4)$ \\
\hline
\end{tabular}

Source: our analysis based on customer ratings posted on TripAdvisor

After that, we evaluated the co-occurrence between positive/negative eWOM and coupon-related factors through the estimation of correlations
Fabio Cassia

Francesca Magno

Marta Ugolini

Does social couponing

stimulate positive eWOM

and online referrals 
coefficients (Phi coefficients). Through this calculation, it was possible to ascertain which coupon-related factors occurred together with positive/ negative eWOM in the customer reviews. Table 3 shows the results.

Tab. 3: Correlations between positive/negative eWOM and coupon-related factors

\begin{tabular}{|c|c|c|}
\hline & $\begin{array}{l}\text { Positive } \\
\text { eWOM }\end{array}$ & $\begin{array}{l}\text { Negative } \\
\text { eWOM }\end{array}$ \\
\hline \multicolumn{3}{|l|}{ Coupon-related factors } \\
\hline Expectations: Lower for couponers (value for money) & -.035 & -.059 \\
\hline Expectations: Unmet expectations & $-.172^{\star \star}$ & $.188^{\star *}$ \\
\hline Expectations: Met expectations & $.101^{*}$ & -.079 \\
\hline Expectations: Beyond expectations & $.187^{\star \star}$ & $-.151^{\star \star}$ \\
\hline Expectations: Worried (negative reviews) & $.129^{\star \star}$ & -0.71 \\
\hline Booking-related problems & $-.207^{\star *}$ & $.242^{* *}$ \\
\hline Differences between advertised and real conditions & $-.225^{\star \star}$ & $.197^{\star *}$ \\
\hline Lack of transparency & $-.126^{\star *}$ & .068 \\
\hline Push to purchase additional services & -.050 & .000 \\
\hline Treatment: B-level treatment & $-.247^{\star \star}$ & $.164^{* *}$ \\
\hline Treatment: Treated as regular customers & $.137^{\star *}$ & $-.088^{\star}$ \\
\hline Attempts to "cheat" the couponers & $-.287^{\star *}$ & $.324^{* *}$ \\
\hline
\end{tabular}

Source: Source: our analysis, ${ }^{*} \mathrm{p}<0.05 ;{ }^{* *} \mathrm{p}<0.01$

The analysis of correlations suggests that positive customer reviews (positive eWOM) are likely to include statements about the guests' prestay worry mainly due to negative online reviews about the hotel. At the same time, in these reviews the codes "met expectations" and "beyond expectations" occur frequently, suggesting that the initial worry was overcome thanks to a positive experience. In particular, positive eWOM shows a strong correlation with the code "treated as regular customers". Therefore, it is possible to infer that the pre-stay worry was, at least in part, related to the expectation of being treated as b-level customers. This expectation was falsified by the experience, emphasizing positive eWOM.

As regards the customer reviews expressing negative eWOM, several codes co-occur with high frequency: unmet expectations, booking-related problems (such as, the lack of room availability in the desired period), differences between the conditions advertised on the deal and those offered by the hotel, b-level treatment for guests using a coupon and the perception that the hotel had been trying to "cheat" the couponers.

\section{Discussion and conclusions}

This study provides evidence that guests that stay at a hotel using a coupon actively engage in eWOM through customer reviews websites and that such eWOM has prevailingly positive valence. 
The particularly high frequency of positive eWOM may be partly the result of couponers' willingness to show to other people that they were able to get a bargain. Interestingly, the results highlighted a significant difference between the frequency of positive eWOM $(n=380)$ and the frequency of recommendation to stay $(\mathrm{n}=112)$.

This gap may have several explanations. Couponers may be willing to recommend to other people to stay at the hotel only when they experienced a very high level of satisfaction. Alternatively, couponers may have established an unconscious assumption that recommendation to stay would imply paying the full price.

In addition, the findings show that the decision of guests to engage in either positive or negative eWOM about the hotel is influenced by some coupon-related factors which can be directly managed or at least influenced by the hotels.

In particular, hotels that treat coupon users as b-level customers are likely to receive negative eWOM. This may be the case of hotels which approach social couponing as a pure sales promotion tools, thus not considering its medium-term, social effects. For example, the analysis of the reviews highlights that in many cases guests had problems in redeeming their coupons because the hotel had no room availability.

This may suggest that some hotels had sold an extremely high number of coupons but were not prepared to meet the resulting demand, since they overlooked the importance of customer experience. Hence, these hotels were more focused on increasing traffic than on offering a positive experience to coupon users.

Conversely, the findings show that hotels which have received positive eWOM were able to go beyond the pre-stay expectations of coupon users and to overcome their worries. By treating these guests as regular guests, these hotels provided them with high quality experiences.

As a result, coupon users acted as brand ambassadors, engaging in rich eWOM.

Therefore, the results of this study underline that, when evaluating the effectiveness of a social couponing campaign, hotel managers should consider both the short-term increase in sales and the medium-term effects on brand knowledge and reputation, which are strongly influenced by eWOM. As a consequence, hotel managers may decide to implement social couponing as a tool for their online reputation management strategy (Baka, 2016).

This study presents several limitations, mainly related to the small sample of hotels and to the specific characteristics of the research setting. In fact, the average hotel size is much smaller in Italy than in other countries such as the United States.

In addition, none of the hotels considered in this analysis belonged to a chain: actually in Italy social couponing has been almost exclusively used by independent hotels (Cassia et al., 2015). Therefore, it may be useful to conduct similar research in other countries to draw more solid conclusions. 


\section{sinergie}

Vol. 34, N. 100, 2016

\section{References}

ADAY J.B., PHELAN K.V. (2015), "Competitive advantage or market saturation: An in-depth comparison of flash-sale sites through content analysis", Journal of Hospitality Marketing \& Management, vol. 24, n. 3, pp. 287-313.

BAKA V. (2016), "The becoming of user-generated reviews: looking at the past to understand the future of managing reputation in the travel sector", Tourism Management, vol. 53, pp. 148-162.

BEREZINA K., SEMRAD K.J., STEPCHENKOVA S., COBANOGLU C. (2016), "The managerial flash sales dash: Is there advantage or disadvantage at the finish line?", International Journal of Hospitality Management, vol. 54, pp. 12-24.

BLANCO R., MATTHEWS M., MIKA P. (2015), "Ranking of daily deals with concept expansion", Information Processing and Management, vol. 51, n. 4, pp. 359-372.

BOON E. (2013), "A Qualitative Study of Consumer-Generated Videos about Daily Deal Web sites", Psychology and Marketing, vol. 30, n. 10, pp. 843-849.

BOON E., PITT L., OFEK N. (2015), ““'Deal of the day”: An analysis of subscriber purchase behavior", Tourism and Hospitality Research, pp. 1-10.

BOON E., WIID R., DESAUTELS P. (2012), "Teeth whitening, boot camp, and a brewery tour: a practical analysis of 'deal of the day'", Journal of Public Affairs, vol. 12, n. 2, pp. 137-144.

CAPRIELLO A., MASON P. R., DAVIS B., CROTTS J.C. (2013), "Farm tourism experiences in travel reviews: A cross-comparison of three alternative methods for data analysis", Journal of Business Research, vol. 66, n. 6, pp. 778-785.

CASSIA F., MAGNO F., UGOLINI M. (2015), "The perceived effectiveness of social couponing campaigns for hotels in Italy", International Journal of Contemporary Hospitality Management, vol. 27, n. 7, pp. 1598-1617.

CHEAH I., PHAU I., LIANG J. (2015), “Factors influencing consumers' attitudes and purchase intentions of e-deals", Marketing Intelligence and Planning, vol. 33, n. 5, pp. 763-783.

COULTER K.S., ROGGEVEEN A. (2012), "Deal or no deal? How number of buyers, purchase limit, and time-to-expiration impact purchase decisions on group buying websites", Journal of Research in Interactive Marketing, vol. 6, n. 2, pp. 78-95.

COX C. (2015), "Consumer experiences of Accommodation Deals purchased via Social Coupon Promotions: An Australian Perspective", Journal of Hospitality Marketing and Management, vol. 24, n. 6, pp. 609-632.

DROSSOS D.A., MARAGOUDAKIS M., KOKKINAKI F. (2015), "Buying Behavior on Daily-Deal Sites: The Role of Face Value, Product Involvement, Information, and Website Quality", Journal of Internet Commerce, vol. 14, n. 2, pp. 200-232.

EISENBEISS M., WILKEN R., SKIERA B., CORNELISSEN M. (2015), "What makes deal-of-the-day promotions really effective? The interplay of discount and time constraint with product type", International Journal of Research in Marketing, vol. 32, n. 4, pp. 387-397.

HEO C.Y. (2016), "Exploring group-buying platforms for restaurant revenue management", International Journal of Hospitality Management, vol. 52, pp. 154-159. 
KIMES S.E., DHOLAKIA U. (2011), "Restaurant Daily Deals: Customers' Responses to Social Couponing ", Cornell Hospitality Report, vol. 11, n. 20, pp. 1-22.

KRASNOVA H., VELTRI N. F., SPENGLER K., GÜNTHER O. (2013), "Deal of the Day” Platforms: What Drives Consumer Loyalty?”, Business and Information Systems Engineering, vol. 5, n. 3, pp. 165-177.

KUMAR V., RAJAN B. (2012), "Social coupons as a marketing strategy: a multifaceted perspective", Journal of the Academy of Marketing Science, vol. 40, n. 1, pp. 120-136.

LEE I. (2016), "Using Groupon for health and wellness businesses", Business Horizons, vol. 59, n. 4, pp. 369-377.

LEE I., LEE K. (2012), "Social shopping promotions from a social merchant's perspective”, Business Horizons, vol. 55, n. 5, pp. 441-451.

LEE I., YOO S., CHOI M.J., SHON D.H. (2015), "Determinants of Social Shopping Performance in Small and Medium-Sized Social Merchants: Theories and Empirical Evidence", Journal of Small Business Management, vol. 53, n. 3, pp. 735-747.

LO A., WU J., LAW R., AU N. (2014), "Which Promotion Time Frame Works Best for Restaurant Group-buying Deals?", Tourism Recreation Research, vol. 39, n. 2, pp. 203-219.

LUO X., ANDREWS M., SONG Y., ASPARA J. (2014), "Group-buying deal popularity", Journal of Marketing, vol. 78, n. 2, pp. 20-33.

MAGNO F., CASSIA F., UGOLINI M. (2014a), "L'efficacia delle campagne di social couponing: uno studio tra i merchant di Groupon", Mercati e competitività, n. 3, pp. 41-63.

MAGNO F., CASSIA F., UGOLINI M. (2014b), "Local vs. global social couponing sites: a study of merchants' satisfaction", Sinergie, n. 95, pp. 65-74.

MINAZZI R. (2015), Social media marketing in tourism and hospitality, Springer, Cham.

NAKHATA C., KUO H.C. (2014), "Non-price cues utilization during social coupon purchasing-decision", Journal of Product and Brand Management, vol. 23, n. 6, pp. 439-451.

NAKHATA C., KUO H.C. (2016), “Consumer avoidance of specially priced items during social coupon redemption", Journal of Retailing and Consumer Services, pp. 1-7.

ONG B. S. (2015), "Attitudes, Perceptions, and Responses of Purchasers Versus Subscribers-Only for Daily Deals on Hospitality Products", Journal of Hospitality Marketing and Management, vol. 24, n. 2, pp. 180-201.

PARSONS A.G., BALLANTINE P.W., ALI A., GREY H. (2014), "Deal is on! Why people buy from daily deal websites", Journal of Retailing and Consumer Services, vol. 21, n. 1, pp. 37-42.

PICCOLI G., DEV C.S. (2012), "Emerging marketing channels in hospitality: A global study of internet-enabled flash sales and private sales", Cornell Hospitality Report, vol. 12, n. 5, pp. 6-19.

SALDAÑA J. (2009), The coding manual for qualitative researchers, Sage, Thousand Oaks.

SCHUCKERT M., LIU X., LAW R. (2015), "Hospitality and tourism online reviews: recent trends and future directions", Journal of Travel and Tourism Marketing, vol. 32, n. 5, pp. 608-621. 
SIGALA M. (2013), "A framework for designing and implementing effective online coupons in tourism and hospitality", Journal of Vacation Marketing, vol. 19, n. 2, pp. 165-180.

SONG M., PARK E., YOO B., JEON S. (2016), "Is the Daily Deal Social Shopping?: An Empirical Analysis of Customer Panel Data”, Journal of Interactive Marketing, vol. 33, pp. 57-76.

SUBRAMANIAN U., RAO R.C. (2016), "Leveraging Experienced Consumers to Attract New Consumers: An Equilibrium Analysis of Displaying Deal Sales by Daily Deal Websites", Management Science, pp. 1-21.

WU J., KIMES S.E., DHOLAKIA U. (2012), "Restaurant Daily Deals: The Operator Experience", Cornell Hospitality Report, vol. 12, n. 16, pp. 1-22.

YADAV M.S., DE VALCK K., HENNIG-THURAU T., HOFFMAN D.L., SPANN M. (2013), "Social commerce: a contingency framework for assessing marketing potential”, Journal of Interactive Marketing, vol. 27, n. 4, pp. 311323.

YANG W., ZHANG L., MATTILA A.S. (2015), "Luxe for Less How Do Consumers React to Luxury Hotel Price Promotions? The Moderating Role of Consumers' Need for Status", Cornell Hospitality Quarterly, vol. 57, n. 1, pp. 1-11.

\section{Academic or professional position and contacts}

\section{Fabio Cassia}

Researcher of Management

University of Verona - Italy

e-mail: fabio.cassia@univr.it

\section{Francesca Magno}

Research Fellow of Management

University of Bergamo - Italy

e-mail: francesca.magno@unibg.it

\section{Marta Ugolini}

Full Professor of Management

University of Verona - Italy

e-mail: marta.ugolini@univr.it

sinergie

\section{italian journal of management}

ISSN 0393-5108 DOI 10.7433/s100.2016.07 pp. 113-124

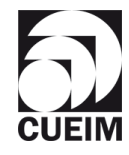

